\title{
ДОСЛІДЖЕННЯ СТАБІЛЬНОСТІ СУПОЗИТОРІЇВ «ФІТОПРОСТ» У ПРОЦЕСІ ЗБЕРІГАННЯ
}

\author{
(C) В. І. Гриценко, О. А. Рубан, С. М. Губарь \\ Національний фрармацевтичний університет, Харків \\ nika.gritsenko@gmail.com
}

\begin{abstract}
Мета роботи. Дослідження стабільності супозиторіїв «Фітопрост» у процесі зберігання.
Матеріали і методи. Об'єктами досліджень стали супозиторії «Фітопрост», що містять у своєму складі сухі рослинні екстракти плодів пальми Сабаль, кореня кропиви та насіння гарбуза, виготовлені на основі твердого жиру методом виливання. У процесі зберігання супозиторіїв за допомогою фрізичних, фрізико-хімічних, срармакотехнологічних, мікробіологічних і аналітичних методів визначали такі показники відповідно до вимог Державної Фармакопеї України (ДФУ): зовнішній вигляд, середню масу, час розпадання, температуру плавлення, рН, кількісний вміст суми стеринів, мікробіологічну чистоту.

Результати й обговорення. Результати проведених досліджень показали, що супозиторії є стабільними при зберіганні у сухому, захищеному від світла місці при кімнатній температурі - протягом одного року, в сухому, захищеному від світла, прохолодному місці - протягом 2 років.

Висновки. Проведено дослідження стабільності ректальних супозиторіїв «Фітопрост» для лікування захворювань передміхурової залози в процесі зберігання. Експериментально доведено, що всі показники якості препарату відповідають вимогам, розробленим проектом методик контролю якості. Встановлено режим зберігання супозиторіїв «Фітопрост» - у сухому темному прохолодному місці протягом 2 років.
\end{abstract}

Ключові слова: супозиторії; стабільність; передміхурова залоза.

Вступ. Доброякісна гіперплазія передміхурової залози (ДГПЗ) $є$ широко розповсюдженою урологічною хворобою чоловіків з віковою тенденцією до прогресуючого зростання: якщо у віці до 60 років ДГПЗ діагностується у 30 - 50 \% чоловіків, то у 80-літньому віці у $90 \%$ чоловіків $€$ морфологічні зміни простати, властиві ДГПЗ. В середньому у 30 \% пацієнтів розвиваються клінічні симптоми, що потребують лікування - розлади сечовипускання, порушення фуункції нирок, еректильної дисфрункції [6, 8, 10].

Згідно з сучасними схемами на початкових стадіях ДГПЗ лікарі рекомендують тривалу медикаментозну терапію, яка включає фрітопрепарати, комплекси БАР яких забезпечують широкий діапазон терапевтичної дії, високу біодоступність та безпеку. Так, в країнах Європи до 60 \% пацієнтів, хворих на ДГПЗ, лікують фрітопрепаратами на основі рослинних екстрактів, серед яких найбільш популярними є препарати з екстрактом плодів пальми Сабаль (Sabal serrulata або Serenoa repens) $[1,2]$.

У нашій країні серед лікарських засобів для лікування ДГПЗ домінують препарати виробництва закордонних фрармацевтичних виробників, тому розробка ефективних, безпечних і доступних вітчизняних препаратів із комплексною терапевтичною дією $є$ актуальною проблемою.
Однією з перспективних лікарських фрорм для лікування захворювань передміхурової залози є супозиторії: вони мають кращу біодоступність та забезпечують терапевтичну дію безпосередньо в простаті [7]. Супозиторії «Фітопрост», створені на кафредрі Заводської технології ліків Національного фрармацевтичного університету, виготовлені на основі твердого жиру і містять у своєму складі фрітокомпозицію з рослинних екстрактів плодів пальми Сабаль, кореня кропиви та насіння гарбуза.

Одним 3 основних показників якості лікарського препарату $є$ стабільність його фрізико-хімічних, фрармакологічних і споживчих характеристик. Вивчення стабільності лікарських препаратів проводять відповідно до Настанови 42-3.3:2004 «Випробування стабільності» [5].

Процеси, що відбуваються при зберіганні лікарських препаратів, можуть призвести до змін їхнього хімічного складу або фрізичних властивостей. Гідроліз, окиснювально-відновлювальні реакції, фротохімічна деструкція та ін. призводять до поступової втрати фрармакологічної активності або до утворення домішок, що змінюють напрямок фрармакологічного есректу.

Під терміном придатності лікарських засобів розуміють період часу, протягом якого вони повинні

ISSN 2312-0967. Pharmaceutical review. 2017. № 1 
Фармацевтична технологія, біофармація, гомеопатія Pharmaceutical technology, biopharmacy, homeopathy

повністю зберігати свою терапевтичну активність, нешкідливість і за рівнем якісних і кількісних характеристик відповідати вимогам нормативної документації.Термін придатності препарату залежить від багатьох фракторів, при цьому зміна будь-якого показника протягом строку зберігання свідчить про негативні процеси, що відбуваються у складі препарату $[4,9]$.

Мета роботи - дослідження стабільності супозиторіїв «Фітопрост» в процесі зберігання.

Матеріали і методи. Об'єктами досліджень стали супозиторії «Фітопрост», що містять у своєму складі сухі рослинні екстракти плодів пальми Сабаль, кореня кропиви та насіння гарбуза, виготовлені на основ твердого жиру методом виливання. Супозиторії були закладені на зберігання при двох температурних режимах:

1) при температурі $12,0 \pm 3{ }^{\circ} \mathrm{C}$;

2) при температурі $25,0 \pm 2{ }^{\circ} \mathrm{C}$ та відносній вологості $60 \pm 5 \%$.

Протягом експерименту супозиторії зберігали в контурних чарункових упаковках із полівінілхлоридної плівки.

У процесі зберігання супозиторіїв за допомогою фрізичних, фрізико-хімічних, фрармако-технологічних, мікробіологічних і аналітичних методів визначали такі показники: зовнішній вигляд, середню масу, час розпадання, однорідність, температуру плавлення,
pH, кількісний вміст суми стеринів, мікробіологічну чистоту згідно з ДФУ [3].

Мікробіологічні дослідження проводили на базі Державної установи «Інститут мікробіології та імунології ім. І. І. Мечникова» відповідно до вимог ДФУ. Кількісне визначення рослинних екстрактів в препараті «Фітопрост» проводили методом газової хроматограсфії на базі Державної науково-дослідної лабораторії з контролю якості лікарських засобів НФаУ відповідно до вимог ДФУ [3].

Результати й обговорення. Показники якості зразків супозиторіїв «Фітопрост» наведено в таблиці 1.

3 метою визначення стабільності розроблених супозиторіїв у процесі зберігання і для встановлення терміну їх придатності нами були виготовлені та закладені на зберігання декілька серій препарату.

Дослідження на відповідність препарату вимогам проекту МКЯ проводили кожні 3 місяці протягом першого року, кожні 6 місяців протягом 2 року та у кінцевій точці контролю 27 місяців. Дані обробляли за допомогою програм для персонального комп'ютера MS Exel та Статистика 6.0. Результати аналізу супозиторіїв наведені у таблицях 2 і 3.

Згідно $з$ одержаними результатами, супозиторії «Фітопрост», що були закладені на зберігання при температурах $12,0 \pm 3{ }^{\circ} \mathrm{C}$ і 25,0 $\pm 2{ }^{\circ} \mathrm{C}$ та відносній вологості $60 \pm 5 \%$ відповідали вимогам МКя за всіма показниками якості протягом 27 місяців.

Таблиця 1. Показники якості супозиторіїв «Фітопрост»

\begin{tabular}{|c|c|c|}
\hline Показник якості & Вимоги проекту МКя & $\begin{array}{l}\text { Методи } \\
\text { контролю }\end{array}$ \\
\hline Опис & $\begin{array}{l}\text { Супозиторії світло-коричневого кольору, однорідні, без } \\
\text { запаху }\end{array}$ & $\begin{array}{l}\text { ДФУ *, } \\
\text { візуально }\end{array}$ \\
\hline 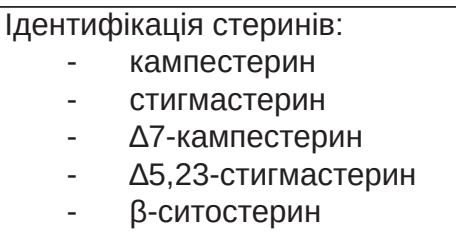 & $\begin{array}{l}\text { Метод газової хроматограсії; } \\
\text { на хроматограмі випробовуваного розчину мають } \\
\text { проявлятися піки із такими відносними часами } \\
\text { утримування: } 0,84 \text { (кампестерин), 0,88 (стигмастерин), } \\
0,93 \text { ( } \Delta 7 \text {-кампестерин), 0,95 ( } \Delta 5,23 \text {-стигмастерин), 1,0 } \\
\text { (ß-ситостерин) }\end{array}$ & ДФУ *, 2.2 .28 \\
\hline Середня маса, г & $2,80 \pm 0,14$ & ДФУ *, 2.9 .5 \\
\hline $\mathrm{pH}$ & Від 5,80 до 6,05 & ДФУ *, 2.2 .3 \\
\hline Час розпадання, хв & Не більше 30 & ДФУ *, 2.9 .2 \\
\hline Температура плавлення, ${ }^{\circ} \mathrm{C}$ & Не більше 37,0 & ДФУ *, 2.2 .15 \\
\hline 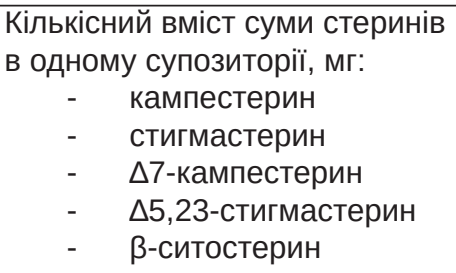 & Не менше 1,7 & ДФУ *, 2.2 .28 \\
\hline $\begin{array}{l}\text { Мікробіологічна чистота: } \\
\text { аеробні мікроорганізми, г }\end{array}$ & $\begin{array}{l}\text { загальне число аеробних мікроорганізмів, в } 1 \text { г } \\
\text { не більше } 10^{3} \\
\text { загальне число дріжджових і плісеневих грибів, в } 1 \text { г } \\
\text { не більше } 10^{2}\end{array}$ & $\begin{array}{l}\text { ДФУ *, 5.1.4, } \\
2.6 .12,2.6 .13\end{array}$ \\
\hline
\end{tabular}

Примітка. * - діюче видання ДФУ.

ISSN 2312-0967. Фармацевтичний часопис. 2017. № 1 
Фармацевтична технологія, біофармація, гомеопатія

Pharmaceutical technology, biopharmacy, homeopathy

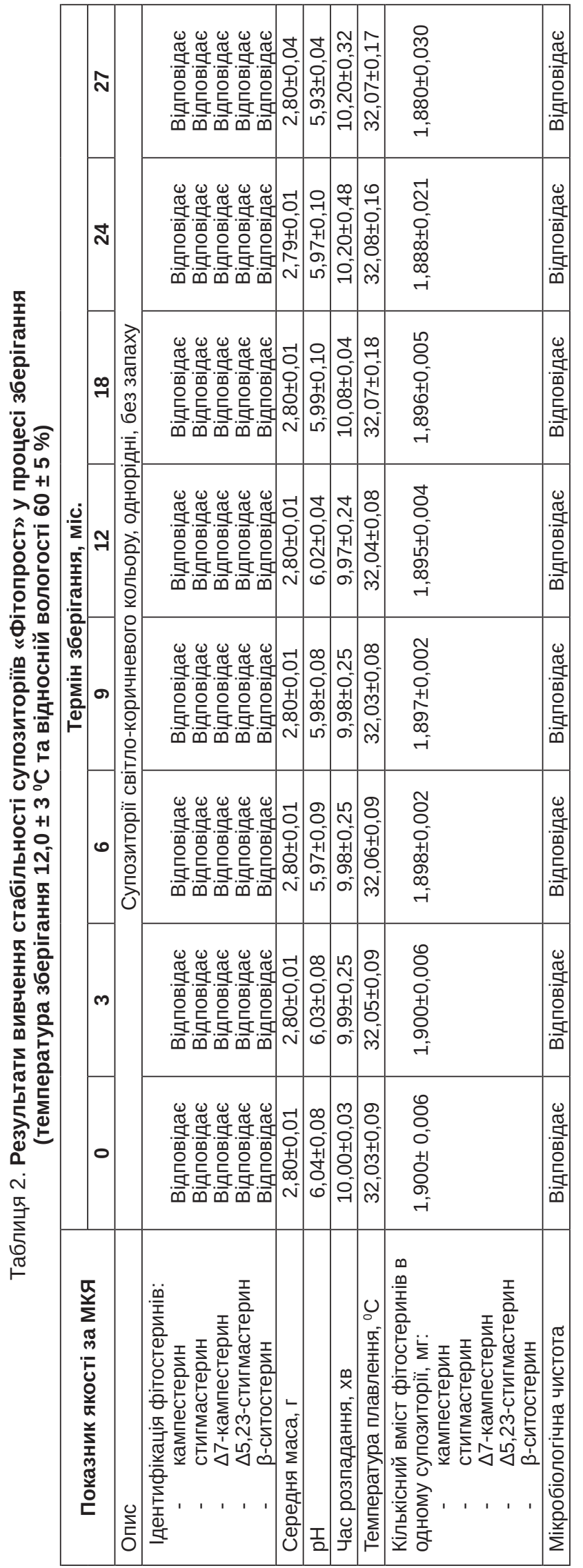

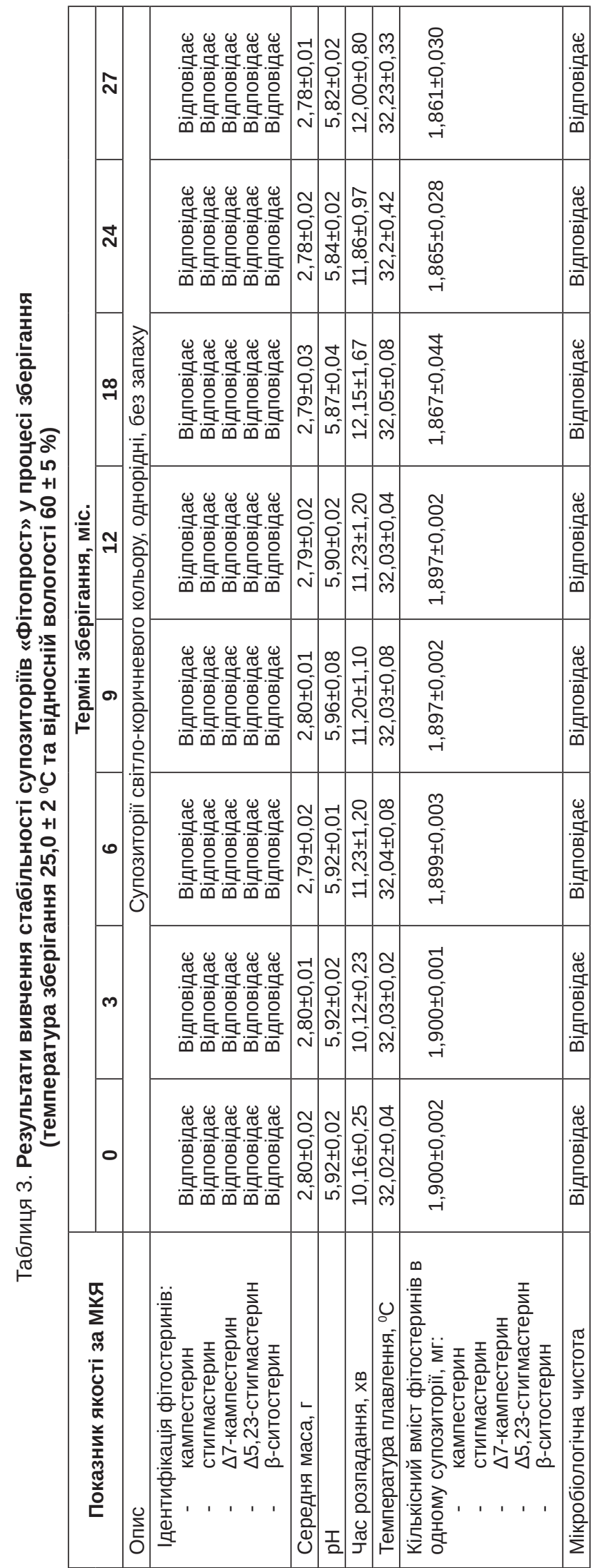

ISSN 2312-0967. Pharmaceutical review. 2017. № 1 
Фармацевтична технологія, біофармація, гомеопатія Pharmaceutical technology, biopharmacy, homeopathy

Одержані результати показали, що досліджувані супозиторії «Фітопрост» $€$ стабільними при зберіганні у сухому, захищеному від світла місці при кімнатній температурі і в сухому, захищеному від світла, прохолодному місці протягом 2 років. Оскільки зберігання супозиторіїв в умовах прохолодного місця сприяє збереженню якості та стабільності протягом більш тривалого строку, саме такий спосіб зберігання є пріоритетним.

Отже, за результатами проведених досліджень, рекомендований режим зберігання супозиторіїв «Фітопрост» - у сухому темному місці при температурі $12,0 \pm 3{ }^{\circ} \mathrm{C}$ та відносній вологості $60 \pm 5$ \% протягом 2 років.

Висновки. 1. Проведено дослідження стабільності супозиторіїв «Фітопрост» у процесі зберігання.
2. Експериментально доведено, що досліджувані супозиторії є стабільними при зберіганні в сухому, захищеному від світла, прохолодному місці протягом 2 років. За таких умов визначено такі показники якості відповідно до вимог ДФУ: зовнішній вигляд, середня маса, $\mathrm{pH}$, час розпадання, температура плавлення, кількісний вміст суми стеринів, мікробіологічна чистота.

3. Результати проведених досліджень показали, що якість препарату відповідає вимогам, зазначеним у проекті методик контролю якості лікарського засобу. Встановлено режим зберігання супозиторіїв «Фітопрост» - у сухому темному місці при температурі $12,0 \pm 3{ }^{\circ} \mathrm{C}$ та відносній вологості $60 \pm 5 \%$ протягом 2 років.

\title{
ИССЛЕДОВАНИЕ СТАБИЛЬНОСТИ СУППОЗИТОРИЕВ «ФИТОПРОСТ» В ПРОЦЕССЕ ХРАНЕНИЯ
}

\author{
В. И. Гриценко, Е. А. Рубан, С. Н. Губарь \\ Национальный фрармацевтический университет, Харьков \\ nika.gritsenko@gmail.com
}

Цель работы. Исследование стабильности суппозиториев «Фитопрост» в процессе хранения.

Материалы и методы. Объектами исследований стали суппозитории «Фитопрост», содержащие в своем составе сухие растительные экстракты плодов пальмы Сабаль, корня крапивы и семян тыквы, изготовленные на основе твердого жира методом выливания. В процессе хранения суппозиториев с помощью фризических, фризикохимических, фрармако-технологических, микробиологических и аналитических методов определяли следующие показатели в соответствии с требованиями Государственной Фармакопеи Украины: внешний вид, среднюю массу, время распадания, температуру плавления, $\mathrm{pH}$, количественное содержание суммы стеринов, микробиологическую чистоту.

Результаты и обсуждение. Результаты проведенных исследований показали, что суппозитории являются стабильными при хранении в сухом, защищенном от света месте при комнатной температуре - в течение одного года, в сухом, защищенном от света, прохладном месте - в течение 2 лет.

Выводы. Проведено исследование стабильности ректальных суппозиториев «Фитопрост» для лечения заболеваний предстательной железы в процессе хранения. Экспериментально доказано, что все показатели качества препарата отвечают требованиям, разработанным проектом методик контроля качества. Установлен режим хранения суппозиториев «Фитопрост» - в сухом темном прохладном месте в течение 2 лет.

Ключевые слова: суппозитории; стабильность; предстательная железа.

\section{RESEARCH ON THE STABILITY OF «PHYTOPROST» SUPPOSITORIES DURING STORAGE}

\author{
V. I. Grytsenko, O. A. Ruban, S. M. Gubar \\ National University of Pharmacy, Kharkiv \\ nika.gritsenko@gmail.com
}

The aim of the work. Research on the stability of «Phytoprost» suppositories during storage.

Materials and Methods. The objects of research were «Phytoprost" suppositories which contain a dry plant extracts Sabal palm fruit, Nettle root and Pumpkin seed in their composition, and were made from solid fat by moulding. During storage of the suppositories using physical, physico-chemical, pharmaco-technological, microbiological and analytical methods the following indicators in accordance with the requirements of the State Pharmacopoeia of Ukraine were determined: appearance, average weight, disintegration time, melting point, $\mathrm{pH}$, sterols content, microbiological purity.

Results and Discussion. Studies showed that the suppositories are stable within 1 year when stored in a dry, dark place at room temperature, and within 2 years when stored in a dry, dark and cool place.

ISSN 2312-0967. Фармацевтичний часопис. 2017. № 1 
Conclusions. The investigations for studying stability of the rectal suppositories «Phytoprost» for benign hyperplasia treatment during storage were made. It was proven that all indicators of the preparation quality into the norm, that listed in the project developed quality control methods. The storage mode of «Phytoprost» suppositories was established. It is within 2 years in a dry dark cool place.

Key words: suppositories; stability; prostate.

\section{Список літератури}

1. Вайс Р. Ф. Фитотерапия: рук. / Р. Ф. Вайс, Ф. Финтельман; пер. с нем. - М. : Медицина, 2004. - 552 с.

2. Гриценко В. І. Наукове обґрунтування складу та технології лікарських препаратів для лікування захворювань передміхурової залози: дис. ... д-ра фрармац. наук. : 15.00.01 / В. І. Гриценко. - Харків, 2015. - 331 с.

3. Державна Фармакопея України: в 3 т. / Державне підприємство «Український науковий орармакопейний центр якості лікарських засобів». - 2-е вид. - Харків : Державне підприємство «Український науковий фрармакопейний центр якості лікарських засобів», 2015. - Т. 1. -1128 c.

4. Ляпунов Н. А. Актуальные вопросы хранения лекарственных средств в аптечных учреждениях / Н. А. Ляпунов // Аптека. - 2011. - № 804 (33). - С. 12-16. 5. Настанова 42-3.3:2004 «Випробування стабільності».

6. Тиктинский О. Л. Андрология / О. Л. Тиктинский,
С. Н. Калинина, В. В. Михайличенко. - М. : ООО «Медицинское информационное агентство», 2010. - С. 504520.

7. Толочко К. В. Створення комбінованих супозиторіїв для лікування простатитів: дис. ... канд. фрармац. наук. : 15.00.01 / К. В. Толочко. - Харків, 2013. - 186 с. 8. The development of human benign prostatic hyperplasia with age / S. J. Barry, D. S. Coffey, P. C. Walsh, L. L. Ewing // J. Urol. - 2004. - Vol. 132. - P. 474-479.

9. Jasinska M. Stability studies of expired tablets of metoprololtartate and propranolol hydrochloride / M. Jasinska, D. Orszulak // Acta Palaniae Pharmaceutica Drug Research. - 2009. - Vol. 66. - P. 697-701.

10. Nickel J. C. Treatment of chronic prostatitis / chronic pelvic pain syndrome / J. C. Nickel // Int. J. Antimicrob. Agents. - 2008. - № 21, Suppl. 1. P. 112-116.

\section{References}

1. Vays RF, Fintelman F. Phytotherapy. [Фитотерапия] Moscow: Medicine; 2004. Russian.

2. Grytsenko VI. Scientific substantiation of the composition and technology of drugs for the treatment of prostate diseases [dissertation]. Kharkiv; 2015. Ukrainian.

3. Derzhavna Farmakopeia Ukrainy [State Pharmacopoeia of Ukraine] Kharkiv, 2015. Ukrainian.

4. Liupunov NA. [Topical issues of storage of medicines in pharmacies]. Apt. 2011; 804 (33): 12-6. Russian.

5. Nastanova 42-3.3:2004. Ukrainian.

6. Tiktinskuy OL, Kalinina SN, Mikhaylichenko VV. Andrology. [Андрология] Moscow: Medical news agency; 2010.

Russian.

7. Tolochko KV. Creating a combined suppositories for the treatment of prostatitis [dissertation]. Kharkiv; 2013.

8. Barry SJ, Coffey DS, Walsh PC, Ewing L. L. The development of human benign prostatic hyperplasia with age. J Urol. 2004; 132: 474-9.

9. Jasinska M, Karwowski B, Orszulak D. Stability studies of expired tablets of metoprolol tartate and propranolol hydrochloride. Acta Pol Pharm. 2009; 66: 697-701.

10. Nickel JC. Treatment of chronic prostatitis / chronic pelvic pain syndrome. Int J Antimicrob Agents. 2008; 21 (1): 112-6. 